\title{
INTENTION TO INVEST IN FINANCIAL PRODUCT OF OLDER PRE- RETIREES WITH FINANCIAL SELF EFFICACY AS AN INTERVENING VARIABLE
}

\author{
Liza Handoko 1 \\ Universitas Pelita Harapan, Tangerang, Indonesia \\ liza.handoko@uph.edu \\ Vina C.Nugroho ${ }^{2}$ \\ Universitas Pelita Harapan, Tangerang, Indonesia \\ vina.nugroho@uph.edu \\ Jacquelinda Sandra Sembel ${ }^{3}$ \\ Universitas Pelita Harapan, Tangerang, Indonesia \\ sandra.sembel@uph.edu \\ Diterima 24 Maret 2020 \\ Disetujui 20 April 2020
}

Abstract- This research wants to investigate the effect of financial knowledge, basic individual traits and compound traits towards intention to invest of pre-retirees with the intervening variable of financial self-efficacy. Older pre-retirees have unique psychological and economic position, as they experience their highest level of lifetime earnings while nearing the end of their financial life cycle. Older pre-retirees must find ways to self-regulate their financial environment. One way to deal with this is through the investment scheme. We use modified model to know the factors that affect intention to invest based on their knowledge and personality, with financial self-efficacy as the intervening variable. We involved 160 respondents of 45 years old and older. The result showed that all the hypothesis is rejected except financial knowledge which is positively associated with intention to invest. This result presents that pre-retirees in Indonesia who have good financial knowledge will have intention to invest in financial products.

Keywords: Pre-retirees, intention to invest, financial self-efficacy

\section{Introduction}

Financial condition of people in their senior years has received a lot of attention in recent years. A lack of savings in generating higher pension fund leads to a risk that many pensioners would face financial difficulties in old age (Gough \& Sozou, 2005; Poterba, 2014; Farrar et al., 2018). Many older pre-retirees are financially unprepared for retirement. Saving available income poses a psychological challenge for the pre-retirees, as they prefer spending today than spending tomorrow (Shefrin \& Thaler, 1988; Farrar et al., 2018). These two conditions (save vs spend) 
influence their financial resources in retirement stage. Ability for older pre-retirees to control their financial situation is very important for retirement preparedness.

Previous research by Ameriks et al., (2002) indicates that financial well-being in old age is enhanced through retirement planning. Financial capability consists of internal capabilities (knowledge, skills \& Attitudes) and external capabilities (inclusive financial institutions, beneficial financial products \& services). Both conditions lead every individual to make financial decisions and perform financial behaviors that contribute to their financial well-being (Sherraden, 2013; Rothwell et al., 2016).

Financial capability is the function of three interrelated components: financial knowledge, skills and attitude. From the perspective of rational consumer model, Informed consumers make better financial decisions (Kempson et al., 2005; Rothwell et al., 2016). Financial literacy or financial knowledge is a determinant of pension planning activities and pension planning leads to improved wealth and income security in old age. From all the literary resources gathered, there has been no research studying the influence of psychological characteristics and financial literacy on financial self-efficacy (FSE) in pre-retirees. Based on Asebedo et al., (2018), personality and psychological traits shape FSE as a starting point. In this research, we used the five-factor theory by McCrae and Costca (1999) that represents the effort to construct theory that is consistent with current knowledge about personality.

Pre-retirees have a unique psychological and economic position, as they experience their highest level of lifetime earnings while approaching the end of their financial life cycle. Older preretirees must find ways to self-regulate their financial environment. Commenting on selfregulation, Bandura (1986) stated that none is more central or pervasive than people's judgement to them to deal effectively with different realities. This judgement is better known as Self-Efficacy (Asebedo et al., 2018). Therefore, this study wants to assess the pre-retiree's behavioral intention to invest involving self-efficacy as the intervening variable. However, the financial decision making is rather complex and risky due to the intangibility of financial products and their outcomes.

Sang et al., (2018) sees intention to invest from a different point of view. According to Sang et al., (2018), intention to invest is positively affected by financial knowledge. Another study about intention to invest is offered by Makki et al., (2016) who stated that such intention is positively affected by self-efficacy. Other researches have proved that financial self-efficacy (FSE) has a positive and significant influence on financial behavior and outcomes. Based on these studies, we have an interest to investigate the effect of financial knowledge and basic individual traits towards intention to invest of the pre-retirees with the intervening of financial self-efficacy. However, more researches have to be conducted to understand factors contributing to FSE in Pre-retirees people on behalf of their preparation of retirement while maintaining their FSE. 


\section{Literature Review}

\subsection{Financial Self-efficacy toward Intention to Invest}

Subjective assessment of one's knowledge, skills and ability to manage and control their financial condition is called financial self-efficacy. The social cognitive theory explores the role of cognitive thinking behind motivation and financial behaviour of a person, which links to Financial Self- Efficacy (Mindra and Moya, 2017). Thus, financial self-efficacy (FSE) resembles the ability to control financial aspects of one's life and has a profound impact on behaviour

(Bandura, 1991 in Asebedo and Payne, 2018). An individual with high self-efficacy is likely to analyse, access and use financial products and services and make this kind of individual with FSE is also likely to make an investment prior to their retirement (Ozmete and Hira, 2011 in Asebedo and Payne, 2018). FSE helps them to make a decision on the allocation of their savings and consumption, because most people will choose to increase consumption level as their income increases. This will require a set of behavioral control and mindset setting supported by FSE. So, our first hypothesis is:

\section{H1: FSE is positively associated with Intention to Invest}

\subsection{Financial Knowledge toward Intention to Invest}

Many studies have explored the effect of financial knowledge on financial behavior. Financial literacy defines the level of knowledge in finance and the ability to apply it in improving financial status (Lusardi and Mitchell, 2014). Higher financial knowledge demonstrates highly effective financial decision-making process and favorable financial investment (Sang et al., 2018). Previous research by Farrell et al., (2015) showed that women who have higher FSE are more likely to make an investment. So, overall, they showed the positive relationship. Therefore, our second hypothesis is:

\section{H2: Financial Knowledge is positively associated with Intention to Invest}

\subsection{Financial Knowledge toward Financial Self Efficacy}

Rothwell et al., (2016), define financial Self Efficacy as subjective assessment of one's knowledge, skills and ability to manage and control household finances. Financial self-efficacy has not been studied as objective of financial knowledge, but previous study by Babiarz and Robb (2014) showed positive relationship between Financial knowledge and FSE. Their analysis highlighted the importance of both objective and subjective knowledge, whereas confidence is a significant component of subjective knowledge, and confident consumers are more likely to take action. More knowledgeable consumers have higher self-efficacy.

\section{H3: Financial Knowledge is positively associated with FSE.}

\subsection{Personality towards FSE}

Personality can be defined as a set of organized characteristics held by individuals that uniquely influence their cognitions, motivations, and behaviors in various situations. In other words, personality is an outward expression of one's mental preferences and predispositions (Nabeshima \& Seay, (2015). Mowen (2000) in Asebedo et al., (2018) mentioned personality traits 
provide foundation for shaping specific self-efficacy (eg:FSE). We use big 5 traits by McCrae and Costa (1999) to represent the personality. Previous study by Asebedo et al., (2018), assessed the connection between Big 5 Personality Traits and FSE. The results showed that there is a relationship between Big 5 Traits and FSE.

Previous research by Asebedo et al., (2018), also indicated that higher level of openness to experience is positively correlated with FSE. Open individuals tend to be more creative and broadminded which may lead them to develop more control over their finances. Based on the study conducted by Asebedo et al., (2018) Conscientiousness and Extroversion are positively associated with FSE but not significant in US data. But according to the previous research by Nabeshima and Seay (2015), there is a positive association between conscientiousness and extroversion on net worth. Based on Mowen and Spears (1999) in Asebedo et al., (2018), Agreeableness and Neuroticism have a negative relationship with FSE. So, we can conclude our next hypothesis:

\section{H4: Openness to experience is positively associated with FSE H5: Conscientiousness is positively associated with FSE H6: Extroversion to experience is positively associated with FSE H7: Agreeableness is negatively associated with FSE H8: Neuroticism is negatively associated with FSE}

\subsection{Compound Traits}

Compound traits result from two or more elemental traits and are defined as "unidimensional dispositions emerging from the interplay of elemental traits, from the culture where an individual lives and from the learning history of individual. Compound traits are narrower than elemental traits. Compound traits consist of perceived mastery, positive affect, negative affect, and task orientation (Asebedo et al.,2018). Previous research by Asebedo et al., (2018) showed significant positive relationship between all the compound traits toward FSE. So, our hypothesis are as follows:

H9: Perceived mastery is positively associated with FSE H10: Positive affect is positively associated with FSE H11: Task orientation is positively associated with FSE 


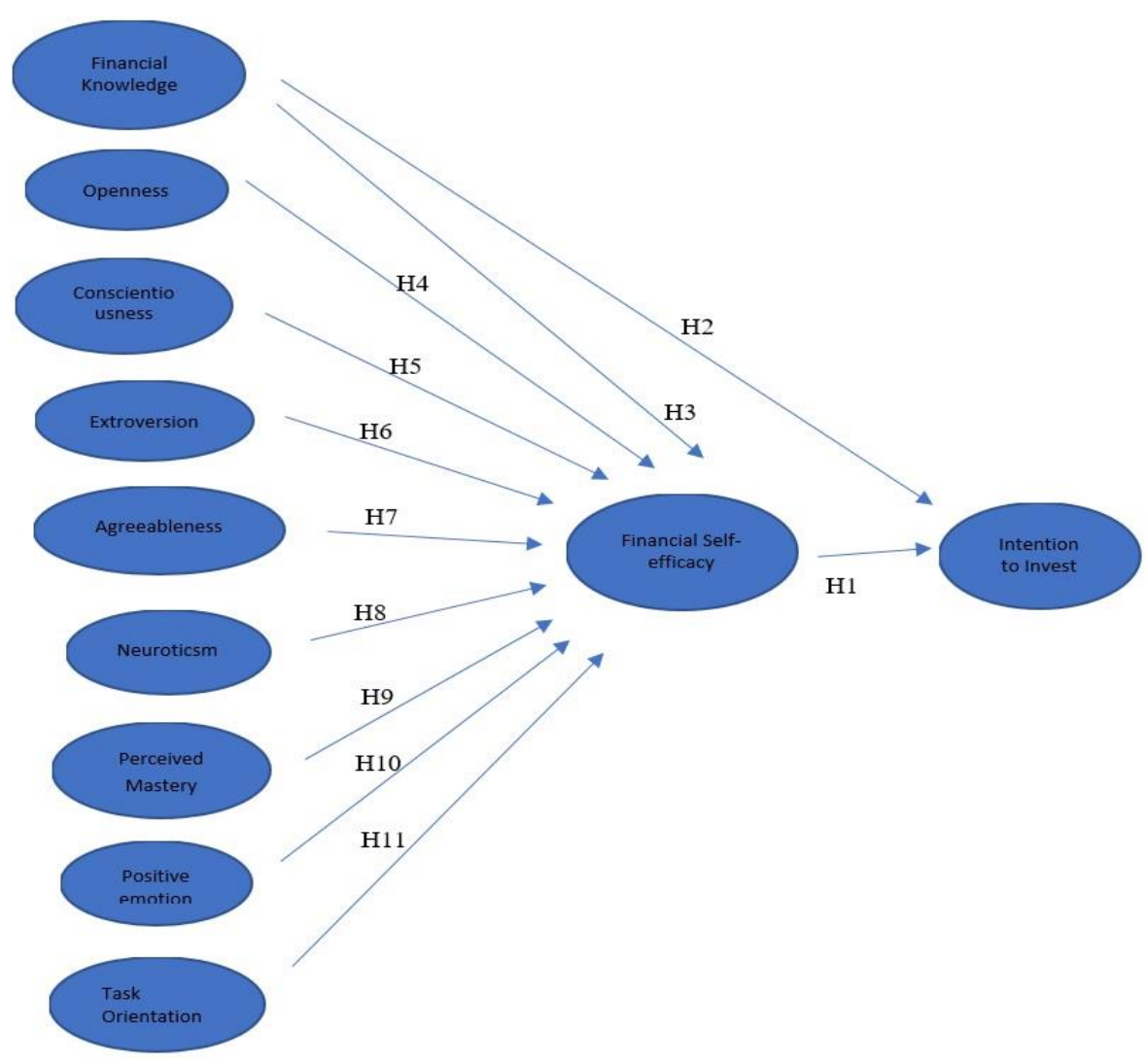

Figure 1. Modified Path Model (Sang et al., (2018) \& Asebedo et al.,(2018))

\section{Methodology}

\subsection{Data and Sample}

Spotlight on retirement in Indonesia 2018, involved several categories of age segments. One of them is the pre-retiree segment. This research adopted the description of the pre-retiree segment (>45 years) based on soa.org. Thus, the research involved people of the age 45 years and above. Our respondents are spread out in all cities in Indonesia, mostly the big cities and familiar or at least know about financial product. An online survey was conducted, and 160 respondents participated in it.

Indicators from Variabel Financial Knowledge are Rooij et al., (2011). Indicators for Financial Self Efficacy are derived from Asebedo \& Payne (2018). While, indicator for Perceived Mastery, Emotion, Task Orientation, Extraversion, Conscientiousness, Openness to experience, Neuroticism and Agreeableness are derived from Asebedo et al.,(2018). For indicators of Intention is derived from wang et al.,(2013). 
Table 1. Model Evaluation

Construct and Indicator

Outer Loading

Financial Knowledge $(\mathrm{AVE}=\mathbf{0 . 5 4 7}, \mathrm{CR}=\mathbf{0 . 7 8 3})$

Mutual Fund can be invested in several

FK1 assets for example stocks \& bonds

0.675

FK2 Stocks normally riskier than bonds

FK3 Stocks usually safer than mutual funds

0.773

Financial Self Efficacy $(\mathrm{AVE}=0.689, \mathrm{CR}=\mathbf{0 . 8 6 9})$

It's hard to stick my spending when

FSE1 unexpected expense arises

I lack confidence in my ability to manage my

FSE2 finances

I worry about running out of money in

FSE3 retirement

Perceived Mastery (AVE $=0.653, \mathrm{CR}=\mathbf{0 . 8 4 6}$ )

I can do just about anything I really set my

PM1 mind to

when I really want to do something, I usually

PM2 find a way to succeed it

I can accomplish something that I really

PM3 want to accomplish

Emotion $(\mathrm{AVE}=1, \mathrm{CR}=1)$

My state of emotion in the last 30 days

Task Orientation $(\mathrm{AVE}=\mathbf{0 . 6 6 5}, \mathrm{CR}=\mathbf{0 . 8 8 8})$

I enjoy making plans for future \& working to

TO1 make them a reality

TO2 My daily activities seem important to me

I'm an active person in carrying out the plans

TO3 I set for my self

I have a good sense about what I'm trying to

TO4 accomplish in my life

Extraversion $(\mathrm{AVE}=\mathbf{0 . 7 4 9}, \mathrm{CR}=\mathbf{0 . 8 9 9})$

E1 I feel comfortable around people

I don't mind starting conversations with new

E2 people

E3 I don't mind being the centre of attention

0.880

Conscientiousness $(\mathrm{AVE}=\mathbf{0 . 5 3 0}, \mathrm{CR}=\mathbf{0 . 8 5 9})$
C1 I am always prepared
0.703
C2 I get chores done right away
0.819
C3 I like order
0.7
C4 I follow a schedule
0.721
C5 I pay attention to details
0.760

Neuroticism $(\mathrm{AVE}=\mathbf{0 . 6 4 2}, \mathrm{CR}=\mathbf{0 . 9 0 0})$

N1 I get stressed out easily

0.845

N2 I worry about things easily

0.838 


$\begin{array}{lll}\text { N3 } & \text { I get angry easily } & 0.798 \\ \text { N4 } & \text { I often feel sad } & 0.799 \\ \text { N5 } & \text { I have frequent mood swings } & 0.721\end{array}$

Agreeableness $(\mathrm{AVE}=\mathbf{0 . 6 0 4}, \mathrm{CR}=\mathbf{0 . 8 8 4})$

A1 Sympathize with other's feeling 0.669

A2 I have a soft hearth $\quad 0.755$

A3 I take time for others $\quad 0.785$

A4 I can feel other people's emotion $\quad 0.836$

A5 I always try to make people feel at ease $\quad 0.830$

Openness to experience $(\mathrm{AVE}=\mathbf{0 . 6 3 4}, \mathrm{CR}=\mathbf{0 . 8 9 6})$

OP1 I have a vivid imagination 0.802

OP2 I have excellent ideas 0.783

OP3 I am quick to understand things $\quad 0.833$

OP4 I am full of ideas $\quad 0.846$

OP5 I am exacting in my work $\quad 0.710$

Intention to Invest $(\mathrm{AVE}=\mathbf{0 . 7 5 4}, \mathrm{CR}=\mathbf{0 . 9 2 5})$

I intend to invest in financial product in the

I1 future short time

0.892

I would recommend people around me to

I2 invest

0.844

I am excited to wait for many new financial

I3 products to be launched

0.821

I4 I plan to invest in the near future 0.914

Source: Data Analysis (2019)

Validity and reliability test were conducted to evaluate the structural model. Validity test was measured through evaluating the AVE and outer loadings. Minimum value required for AVE is 0.5 and minimum outer loading is 0.7 . But, outer loading's value between 0.4 to 0.7 is still considered acceptable as long it can lead to higher AVE (Hair et al.,2014). Based on Table 1, we can conclude that our model's measurement is valid. All the AVEs were above 0.5 and all of the outer loadings are above 0.6. Reliability test was measured through Composite Reliability or CR. Based on Hair et al., (2014), minimum value required for CR is 0.7 and all our results showed that CR's values were above 0.7 .

Table 2. $\mathbf{R}^{2}$

\begin{tabular}{|c|c|}
\hline $\begin{array}{c}\text { Construct } \\
\text { Endogenous }\end{array}$ & Rsquared \\
\hline FSE & 0.308 \\
\hline II & 0.080 \\
\hline
\end{tabular}

Source : Data Analysis (2019) 
Table 2 shows two $\mathrm{R}^{2}$ results of our two endogenous variables. Financial Self Efficacy (FSE) has $\mathrm{R}^{2}$ 0.308. It means all the exogeneous variables such as Financial knowledge, openness to experience, conscientiousness, extroversion, agreeableness, neuroticism, perceived mastery, emotion and task orientation can only explain the FSE 30.8\%. The second endogenous variable, Intention to Invest (II) has $\mathrm{R}^{2}$ 0.080. It means FSE and Financial knowledge as exogeneous variables can only explain intention to invest $8 \%$. The other $92 \%$ might be explained by other variables that have not been covered in this research

\section{Discussion}

Table 3. Sociodemographic

\begin{tabular}{|c|c|c|c|}
\hline Labor Force & & $\mathrm{n}$ & $\%$ \\
\hline & Working & 134 & $84 \%$ \\
\hline & Not Working & 26 & $16 \%$ \\
\hline \multicolumn{4}{|c|}{ Household Status } \\
\hline & Single & 26 & $16 \%$ \\
\hline & Married & 134 & $84 \%$ \\
\hline \multicolumn{4}{|l|}{ Education } \\
\hline & Below SMA & 2 & $1 \%$ \\
\hline & SMA & 23 & $14 \%$ \\
\hline & $\mathrm{S} 1$ & 72 & $45 \%$ \\
\hline & $\mathrm{S} 2$ & 47 & $29 \%$ \\
\hline & S3 & 16 & $10 \%$ \\
\hline \multicolumn{4}{|c|}{ Number of Dependents } \\
\hline & 1-3 People & 117 & $73 \%$ \\
\hline & 4-6 People & 40 & $25 \%$ \\
\hline & Above 6 People & 3 & $2 \%$ \\
\hline \multicolumn{4}{|c|}{ Presence of Debt } \\
\hline & Yes & 82 & $51 \%$ \\
\hline & No & 78 & $49 \%$ \\
\hline \multicolumn{4}{|c|}{ Expenses in one month } \\
\hline & Below IDR 20 mio & 108 & $68 \%$ \\
\hline & IDR $21 \mathrm{Mio}-40 \mathrm{Mio}$ & 33 & $21 \%$ \\
\hline & IDR 41 Mio - 60 Mio & 9 & $6 \%$ \\
\hline & Above IDR 60 Mio & 11 & $7 \%$ \\
\hline \multicolumn{4}{|c|}{ Homeownership Status } \\
\hline & Homeowner without mortgage & 22 & $14 \%$ \\
\hline & Homeowner with mortgage & 104 & $65 \%$ \\
\hline & Not Homeowner & 34 & $21 \%$ \\
\hline
\end{tabular}

Source: Data Analysis (2019)

Table 1 represents our respondents' socio-demographic profile. Based on this table, most our respondents' education levels are bachelor degree and above. It will lead to a good assumption that most of them are familiar with investment and financial knowledge. About $84 \%$ from our respondents are still working and have a permanent job. The rest $16 \%$ are not working because most of them are housewives. About $73 \%$ of our respondents have to finance a few members of their households or only themselves and their spouse. Most of our respondents have children who 
are married and capable to finance their own family, so, they do not have an obligation anymore to finance their children. This condition also affected their expenses in one month. Most of them (68\%) have expenses below IDR 20 million per month. If they still have children in college or school, their expenses in one month will be more than IDR 20 million. We can also conclude that half of the respondents still have debts $(51 \%)$ and $65 \%$ still have a mortgage loan. This presence of debt might not be a bad sign for their financial condition. Thus, mortgage loans could be one of their investment toward fixed assets

Table 4. Hypothesis Test

\begin{tabular}{|l|l|l|l|}
\hline Hypothesis & Coefficient & P value & Decision \\
\hline H1 : Financial Self Efficacy is positively associated with intention to invest & -0.049 & 0.597 & Not support \\
\hline H2 : Financial Knowledge is positively associated with Intention to invest & 0.269 & 0 & significant and support \\
\hline H3 : Fin.Knowledge is positively associated with FSE & -0.206 & 0.01 & Signifcant but not support \\
\hline H4 : Openness to experience is positively associated with FSE & -0.082 & 0.426 & Not support \\
\hline H5 : Conscientiousness is positively associated with FSE & -0.176 & 0.094 & Not support \\
\hline H6 : Extraversion is positively associated with FSE & -0.031 & 0.715 & Not support \\
\hline H7 : Agreeableness is negatively associated with FSE & 0.005 & 0.959 & Not support \\
\hline H8 : Neuroticism is negatively associated with FSE & 0.431 & 0.000 & significant but not support \\
\hline H9 : Perceived mastery is positively associated with FSE & -0.037 & 0.722 & Not support \\
\hline H10 : Positive affect is positively associated with FSE & 0.026 & 0.701 & Not support \\
\hline H11 : Task Orientation is positively associated with FSE & 0.056 & 0.661 & Not support \\
\hline
\end{tabular}

Source: Data Analysis (2019)

First hypothesis, Financial Self-Efficacy is positively associated with intention to invest in not supported by our result. This contradicts with the previous research by Asebedo and Payne (2018). Our result from respondents in Indonesia showed that FSE is negatively associated with intention to invest and is not significant. It means, individuals with higher FSE don't necessarily have a willingness to invest in financial assets. Second hypothesis, Financial Knowledge is positively associated with intention to invest that has been supported by the result. This result aligns with previous research that shows that higher level of financial knowledge is associated with stronger likelihood to invest. It means, people who have financial knowledge are more likely to invest than people who are not. Our sociodemographic result can also support this statement: $45 \%$ from our respondents are bachelor-degree holders and $29 \%$ are master-degree holders. This explains why they are familiar with financial knowledge. As we mentioned previously, half of the respondents still have debts $(51 \%)$ and $65 \%$ still have a mortgage loan. This presence of debt might not be a bad sign for their financial condition. Thus, mortgage loans could be one of their investment towards fixed assets.

Third hypothesis, Financial Knowledge is positively associated with FSE, is not supported even when the $\mathrm{p}$ value is significant, because the coefficient is negative. It can be concluded that, financial knowledge is negatively associated with Financial Self-Efficacy. It means, higher financial knowledge doesn't necessarily make an individual to have higher self-efficacy. According to Bandura (1991), self-efficacy is defined as a person's subjective judgement of his or her ability to control his or her life. So, higher knowledge, doesn't guarantee he or she has higher FSE. Some of our respondents have outstanding education such as doctoral degree, but this doesn't 
mean they have good judgement of financial condition. Most respondents might have lower financial knowledge, but they have higher FSE. This is possible, because they might gain a lot of money not from investments. So, it isn't necessary for them to have knowledge of financial products. This hypothesis is supported by Rothwell et al., (2018) who stated that people may be highly confident in their ability to manage finances but have relatively little objective knowledge and vice-versa.

Among the big five personality traits, only Neuroticism has significant impact on FSE, but does not support H8. Based on our result, Neuroticism has significant positive affect on FSE. This result contradicts with the previous research by Asebedo et al., (2018) that revealed that negative emotional states like Neuroticsm can lead to negative relationship with FSE. Our research supported by Hilbig (2008), that revealed individual with high neuroticsm are more likely to experience shame upon failure and be genuinely motivational in nature. Moreover, based on Hofstede cultural dimension, Indonesia has 14 score and US has 91 score of individualism. It means, Indonesian people are very affected by society, so they are very afraid with failure because they do not want people around them recognize their weaknesses and it will lead high anxiety around Indonesian people. Lately, this anxiety will be a motivation for them to gain success and will lead high FSE.

The other four personality traits from $\mathrm{H} 4$ to $\mathrm{H} 7$ did not significantly affect FSE. This is also supported by Asebedo et al., (2018) in US, that conscientiousness, extroversion and agreeableness did not significantly affect the FSE. But, in the US, Openness to experience significantly has positive affect on FSE, but not in Indonesia. It could happen because people in Indonesia aged 45 years above tend to be conservative and risk averse. $\mathrm{H} 9, \mathrm{H} 10$ and $\mathrm{H} 11$ represent compound traits on FSE. But from our results, all the compound traits do not significantly affect the FSE. On the other hand, previous research by Asebedo et al., (2018) showed that all of the compound traits have significant effect on FSE.

\section{Conclusion}

Results of our hypothesis tests showed that all the hypothesis is rejected except $\mathrm{H} 2$, which is financial knowledge that is positively associated with intention to invest. The results showed that older pre-retirees in Indonesia who have good financial knowledge will have intention to invest in the financial product. The rest who are not familiar with the financial product will not invest. Surprisingly, the rest of the hypothesis is not supported by our results. For example, in Indonesia financial knowledge is negatively associated with Financial Self-Efficacy because they might gain a lot of money not from investment. So, it is not necessary for them to have knowledge of financial products. It is also supported by data from KSEI that stated that, from 260 Million people in Indonesian, only 1,2 Million people invested in capital market. This result is different from previous the research by Asebedo et al., (2018) in the US. This is perhaps due to the different socio-cultural profile, lifestyle, and characteristics between people in US and in Indonesia. 


\section{REFERENCES}

Asebedo, S.D., Seay, M.C., Archuleta, K., \& Brase, G. (2018). The Psychological Predictors of Older Prereturees's Financial Self-Efficacy. Journal of Behavioral Finance, 53(2), 488-519. https://doi.org/10.1111/joca.12199

Babiarz, P., \& Robb, C.A. (2014). Financial Literacy and Emergency Saving. J Fam Econ Iss, 35, 40-50.

Danes, S. M., \& Haberman, H. (2007). Teen financial knowledge, self-efficacy, and behavior: A gendered view. Journal of Financial Counseling and Planning, 18(2).

Farrar, S., Moizer, J., Lean, J., \& Hyde, M. (2018). Gender, Financial Literacy, and Preretirement Planning in the UK. Journal of Woman \& Aging, 31(4), 319-339. https://doi.org/10.1080/08952841.2018.1510246

Farrell, L., Fry, T.R.L., Risse, L. (2015). The Significance of Financial Self-Efficacy in Explaining Women's Personal Finance Behaviour. Journal of Economic Psychology.

Hair, J.F., Black,W.C., Babin, B.J., \& Anderson, R.E. (2014). Multivariate Data Analysis : a global perspective. NJ : Pearson Prentice Hall.

Hilbig, B.E. (2008). Individual Differences in Fast-and-Frugal Decision Making: Neuroticism and the Recognition Heuristic. Journal of Research in Personality, 42(6), 1641-1645. https://doi.org/10.1016/j.jrp.2008.07.001

Hofstede .(2019). Retrived from https://www.hofstede-insights.com/countrycomparison/indonesia, the-usa/

Kompas .(2019). Retrieved from https://money.kompas.com/read/2019/06/26/141032126/permei-2019-investor-pasar-modal-indonesia-mencapai-19-juta

Lusardi, A. and Mitchell, O.S. (2014). The economic importance of financial literacy: theory

and evidence, Journal of Economic Literature, 52(1), 5-44. https://doi.org/10.1257/jel.52.1.5

McCrae, R,R.,Costa, P.T. (1999). A Five-Factor Theory of Personality. Handbook of Personality: Theory and Research, 2. 139-153.

Nabeshima, G., and M. C. Seay.(2015). Wealth and Personality: Can Personality Traits Make Your Clients Rich?. Journal of Financial Planning, 28, 50-57.

Rothwell, D,W., Khan, M,N., \& Cherney,K. (2016). Building Financial Knowledge Is Not Enough: Financial Self-Efficacy as a Mediator in the Financial Capability of Low-Income Families. Journal of Community Practice, 24(4), 368-388. https://doi.org/10.1080/10705422.2016.1233162

Sang, L,T., Mail, R., And Karim, M.R., Karamah, Z., Jaidi, J., \& Noordin, R. (2018). A Serial Mediation Model of Financial Knowledge on The Intention to Invest : The Central Role of Risk Perception and Attitude. Journal of Behavioral and Experimental Finance, 20, 74-79. https://doi.org/10.1016/j.jbef.2018.08.001

Van Rooij, M., Lusardi, A.,Alessie, R. (2011). Financial Literacy and Stock Market Participation. $\begin{array}{llll}\text { Journal of Financial } & \text { Economics, } & \text { 101(2), }\end{array}$ https://doi.org/10.1016/j.jfineco.2011.03.006 
Wan, Y,S., Yeh, C,H., \& Liao, Y,W.(2013). What Drives Purchase Intention in The Context of Online Content Services? The Moderating Role of Ethical Self-Efficacy for Online Piracy. International Journal of Information Management, 33(1), 199-208. https://doi.org/10.1016/j.ijinfomgt.2012.09.004

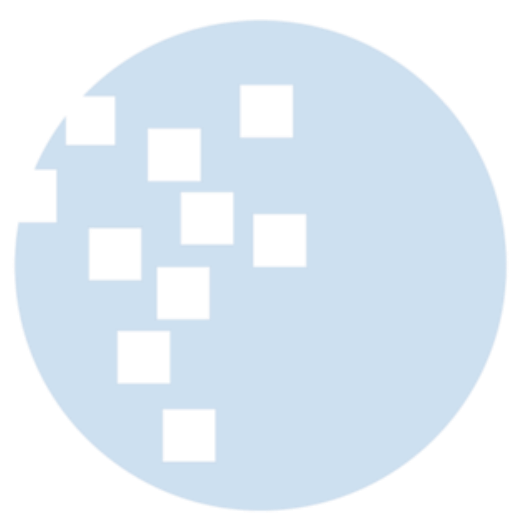

